\title{
Mangrove Above-Ground Biomass and Carbon Stock in the Karimunjawa-Kemujan Islands Estimated from Unmanned Aerial Vehicle-Imagery
}

\author{
Anindya Wirasatriya ${ }^{1,2, *(\mathbb{D}, \text { Rudhi Pribadi }}{ }^{3}$, Sigit Bayhu Iryanthony ${ }^{2} \mathbb{D}$, Lilik Maslukah ${ }^{1}$, \\ Denny Nugroho Sugianto ${ }^{1}$, Muhammad Helmi ${ }^{1,2}$, Raditya Rizki Ananta ${ }^{3}$, Novi Susetyo Adi ${ }^{4}$, \\ Terry Louise Kepel ${ }^{4}$, Restu N. A. Ati ${ }^{4}$, Mariska A. Kusumaningtyas ${ }^{4}$, Rempei Suwa ${ }^{5}$, Raghab Ray ${ }^{6}$ (D), \\ Takashi Nakamura $^{7}$ (D) and Kazuo Nadaoka ${ }^{7}$
}

check for updates

Citation: Wirasatriya, A.; Pribadi, R.; Iryanthony, S.B.; Maslukah, L.; Sugianto, D.N.; Helmi, M.; Ananta, R.R.; Adi, N.S.; Kepel, T.L.; Ati, R.N.A.; et al. Mangrove Above-Ground Biomass and Carbon Stock in the Karimunjawa-Kemujan Islands Estimated from Unmanned Aerial Vehicle-Imagery. Sustainability 2022, 14, 706. https://doi.org/ $10.3390 /$ su14020706

Academic Editor: Sharif Ahmed Mukul

Received: 19 November 2021

Accepted: 5 January 2022

Published: 9 January 2022

Publisher's Note: MDPI stays neutral with regard to jurisdictional claims in published maps and institutional affiliations.

Copyright: () 2022 by the authors Licensee MDPI, Basel, Switzerland. This article is an open access article distributed under the terms and conditions of the Creative Commons Attribution (CC BY) license (https:// creativecommons.org/licenses/by/ $4.0 /)$.
1 Department of Oceanography, Faculty of Fisheries and Marine Science, Universitas Diponegoro, Semarang 50275, Indonesia; lilik_masluka@yahoo.com (L.M.); dennysugianto@yahoo.com (D.N.S.); muhammadhelmi69@gmail.com (M.H.)

2 Coastal and Ocean Remote Sensing Laboratory, Center for Coastal Rehabilitation and Disaster Mitigation Studies, Universitas Diponegoro, Semarang 50275, Indonesia; sigitbayhuiryanthony@gmail.com

3 Department of Marine Science, Faculty of Fisheries and Marine Science, Universitas Diponegoro, Semarang 50275, Indonesia; rudhi_pribadi@yahoo.co.uk (R.P.); raditya.adit61@gmail.com (R.R.A.)

4 Center for Marine Research, Ministry of Marine Affairs and Fisheries, Jalan Pasir Putih, Ancol Timur, Jakarta 14430, Indonesia; novisusetyoadi@kkp.go.id (N.S.A.); kepel74@gmail.com (T.L.K.); restu.noviansyah@gmail.com (R.N.A.A.); astridkusuma@kkp.go.id (M.A.K.)

5 Forestry Division, Japan International Research Center for Agricultural Sciences (JIRCAS), 1-1 Ohwashi, Tsukuba 305-8686, Japan; swrmp2005@yahoo.co.jp

6 Atmosphere and Ocean Research Institute, The University of Tokyo, Kashiwa 277-8564, Japan; raghab.ray@aori.u-tokyo.ac.jp

7 School of Environment and Society, Tokyo Institute of Technology, Tokyo 152-8552, Japan; nakamura.t.av@m.titech.ac.jp (T.N.); nadaoka.k.aa@m.titech.ac.jp (K.N.)

* Correspondence: aninosi@yahoo.co.id; Tel.: +62-247-474-698

Abstract: Blue carbon ecosystems in the Karimunjawa Islands may play a vital role in absorbing and storing the releasing carbon from the Java Sea. The present study investigated mangrove above-ground biomass (AGB) and carbon stock in the Karimunjawa-Kemujan Islands, the largest mangrove area in the Karimunjawa Islands. Taking the aerial photos from an Unmanned Aerial Vehicle combined with Global Navigation Satellite System (GNSS) measurements, we generated Digital Surface Model (DSM) and Digital Terrain Model (DTM) with high accuracy. We calculated mangrove canopy height by subtracting DSM from DTM and then converted it into Lorey's height. The highest mangrove canopy is located along the coastline facing the sea, ranging from $8 \mathrm{~m}$ to $15 \mathrm{~m}$. Stunted mangroves $1 \mathrm{~m}$ to $8 \mathrm{~m}$ in height are detected mainly in the inner areas. AGBs were calculated using an allometric equation destined for the Southeast and East Asia region. Above-ground carbon biomass is half of AGB. The AGB and carbon biomass of mangroves in the Karimunjawa-Kemujan Islands range from $8 \mathrm{Mg} / \mathrm{ha}$ to $328 \mathrm{Mg} / \mathrm{ha}$, and from $4 \mathrm{MgC} /$ ha to $164 \mathrm{MgC} / \mathrm{ha}$, respectively. With a total area of $238.98 \mathrm{ha}$, the potential above-ground carbon stored in the study area is estimated as $16,555.46 \mathrm{Mg}$.

Keywords: above-ground biomass; carbon stock; mangrove; Karimunjawa Islands; aerial photo

\section{Introduction}

It has been widely known that anthropogenic carbon dioxide emissions $\left(\mathrm{CO}_{2}\right)$ become the main contributor to climate change. Friedlingstein et al. [1] reported the rapid increase of fossil fuel use, land-use change, and cement manufacture increased the $\left(\mathrm{CO}_{2}\right)$ in the atmosphere over the last decade. From the observations from NOAA-ESRL, the atmospheric $\mathrm{CO}_{2}$ concentrations in 2000, 2010, and 2018 were 369.55 ppm, 389.90 ppm, and 409.68 ppm, 
respectively [2]. Thus, reducing the $\mathrm{CO}_{2}$ concentration in the atmosphere is one of the critical measures for combating climate change.

On the other hand, coastal ecosystems, i.e., mangroves, seagrass, and salt marshes, play important roles as the blue carbon ecosystems, referring to their abilities to sequester the amounts of carbon per unit area more significantly than the terrestrial forest [3]. In the tropics, mangrove and seagrass ecosystems have become the major blue carbon ecosystem [4]. Thus, conserving the blue carbon ecosystems has become one of the strategies for mitigating anthropogenic carbon emissions.

Among the three blue carbon ecosystems, mangroves have the greatest above-ground biomass due to their larger and woody growth forms. They can store greater carbon than the other blue carbon ecosystems [5]. Furthermore, Kauffman et al. [6] found that mangrove carbon stock is much higher than that of terrestrial forest due to their ability to store more carbon in their above-ground biomass and below ground as root and sediment, e.g., [3,7-9]. Mangroves' biomass can store $10 \%$ of total atmospheric $\mathrm{CO}_{2}$, but only $0.7 \%$ is kept by the global forest [8].

The Karimunjawa Islands are located in the center of the Java Sea and have been under the authority of the Karimunjawa National Park since 1999, based on the Decree of The Minister of Forestry (SK Menhut) No.78/Kpts-II/1999. Therefore, mangroves in Karimunjawa are well conserved. On the other hand, the Java Sea is known as the carbon source area as investigated by in-situ measurements using a $\mathrm{pCO}_{2}$ analyzer over a 4-year period (2010-2013) [10]. Generally, Indonesian seas act as a $\mathrm{CO}_{2}$ source since the seawater $\mathrm{pCO}_{2}$ is supersaturated relatively to the atmosphere by $15.9 \pm 8.6 \mu \mathrm{atm}$. Furthermore, taking the benefit of satellite measurements that are spatially and temporally continuous and wide coverage monitoring, Wirasatriya et al. [11] revealed the seasonal variation of carbon flux in the Java Sea. The releasing carbon to the atmosphere occurs at maximum during the first transition season (April-May). Focusing on the seas of the Karimunjawa Islands, which was left blank by Kartadikaria et al. [10] and Wirasatriya et al. [11], Latifah et al. [12] also found that the seas of the Karimunjawa Island act as a carbon source by conducting in-situ $\mathrm{CO}_{2}$ measurement. Thus, it is crucial to investigate the role of the mangrove ecosystems in the Karimunjawa Islands as a contra role of the Java Sea in releasing carbon for a future possibility of the calculating carbon budget in the region. As the largest mangrove area in the Karimunjawa Islands, the mangrove forest on the Karimunjawa-Kemujan Islands is the focus of the present study's investigation.

The traditional measurement of mangrove biomass is conducted by direct tree measurements in the field, including height, canopy/crown area, and diameter at breast height $(\mathrm{DBH})$ within the designated plots, which are then applied the allometric equations to obtain tree above-ground biomass (AGB) $[13,14]$. However, these in situ measurements are sometimes difficult to conduct in dense mangrove stands or remote areas with limited access. These issues lead to poor survey coverage and measurement errors, which in the end, can cause the underestimation of measured mangrove biomass [15].

Due to its extensive observational coverage and continuous monitoring, satellite remote sensing answers the limitation of traditional mangrove surveys for investigating mangroves' distribution and structure [16]. The application of satellite remote sensing has been established to map the tree height and mangrove biomass worldwide, e.g., [17-25]. These satellite-based mangrove biomass measurements give the optimum advantages for monitoring change at a broad scale [26]. However, at least two issues should be solved to map the local scale's mangrove biomass and carbon stock. The first issue is related to the spatial resolution of the data. The satellite data mentioned above have a spatial resolution of more than $10 \mathrm{~m}$ which are not intended to capture fine-scale heterogeneity related to the mangrove biomass and carbon stock assessment [27].

In the present study, we used Unmanned Aerial Vehicle (UAV) imagery to solve the coarse spatial resolution issue posed by satellite remote sensing methods to investigate the mangrove AGB and carbon stock in the Karimunjawa-Kemujan Islands. Since the last decade, the application of UAV for research in ecology has rapidly developed [28], 
mainly for forestry [29] and agriculture [30] to collect the structural measurements of plants. For mangrove applications, UAV-imagery was utilized by Jones et al. [15] to generate high-resolution three-dimensional canopy models, site-based assessments of mangrove AGB and carbon stocks over hundreds of hectares. Furthermore, Navarro et al. [31] also successfully used the structure of Motion and Multi-View Stereo reconstructions from UAV data to estimate the height, canopy diameter and AGB of natural and rehabilitated mangrove forests across two regions of the southeastern coast of Australia.

The second issue is related to the allometric equation for calculating mangrove AGB. As an analogy to an allometric equation for estimating individual tree AGB, the Lorey's mean canopy height $\left(\mathrm{H}_{\mathrm{m}}\right)$-AGB relationships showed distinct regional differences in mangroves on the basis of field research [32], i.e., the $\mathrm{H}_{\mathrm{m}}-\mathrm{AGB}$ relationship from East Africa and Bangladesh are different to that from America. In contrast, the investigation of Saatchi et al. [33] found that this regional difference is less pronounced in the terrestrial tropical forests based on the extensive global dataset. This indicates that mangroves have their own local characteristic of the $\mathrm{H}_{\mathrm{m}}$-AGB relationship driven by the other forest structural parameters such as cumulative basal area, mean wood density $\left(\rho_{\mathrm{m}}\right)$, and environmental parameters [34]. Thus, applying the allometric equation cannot be generalized and should consider the local characteristic of the $\mathrm{H}_{\mathrm{m}}$-AGB relationship. Fortunately, Suwa et al. [34] have developed an allometric equation designated for the Southeast and East Asia region, including the Karimunjawa area, for estimating mangrove AGB. For developing the equation, they have considered the different species distribution in their study area. Thus, this allometric equation is only applicable for the area of the Southeast and East Asia region. Testing the canopy height $\left(\mathrm{H}_{\mathrm{m}}\right)$, basal area weighted mean wood density $\left(\rho_{\mathrm{m})}\right.$ and their combination as explanatory variables to estimate AGB for mangroves, they found that the difference of the $\mathrm{H}_{\mathrm{m}}-\mathrm{AGB}$ relationship among their study sites is partly explained by the differences of $\rho_{\mathrm{m}}$. Thus, they encourage using $\mathrm{H}_{\mathrm{m}}$ as a proxy to estimate mangrove AGB using remote sensing data in the Southeast and East Asia region.

In the present study, we built a high-resolution three-dimensional model of mangrove forest using UAV-imageries, corrected using GNSS and in-situ tree height measurements and then adopted Suwa et al [34],'s equation for estimating mangrove AGB in the Karimunjawa-Kemujan Islands. This is the first high-resolution UAV-based mangrove AGB map which considers the Hm-AGB relationship developed from local characteristics.

\section{Materials and Methods}

\subsection{Study Area}

Our study area is located on the Karimunajawa and Kemujan Islands, the two main islands of the Karimunjawa Islands, precisely on the strait between the Karimunjawa and Kemujan islands, where the densest mangroves in Karimunjawa exist (Figure 1a). This dense mangrove condition makes the two islands look connected, as seen from the satellite image (Figure 1a). Based on our field observation, mangroves in the Karimunjawa-Kemujan Islands have strong zoning with the dominant species in each zone. Suwa et al. [34] reported that the dominant mangrove species in the Karimunjawa-Kemujan Islands are Rhizophora stylosa, Lumnitzera littorea, and Rhizophora apiculata. There are 45 mangrove species in this area, consisting of 27 true mangroves and 18 mangrove associates. Rhizophora stylosa is the most dominant species in the study site. Mangrove structural zonations can be divided into three formations from land to seaward margin. Low multi-stem stands of Ceriops tagal and Lumnitzera racemosa dominates the outermost landward margin. The middle part is dominated by the single and multi-stem low-closed forest of highly mixed formations of Ceriops tagal, Lumnitzera sp., Rhizophora sp. and Bruguiera gymnorhiza. The formation of a multistem closed forest of Rhizophora mucronata and some individual Bruguiera gymnorhiza and Xylocarpus granatum dominate the shoreline area [35-37]. 


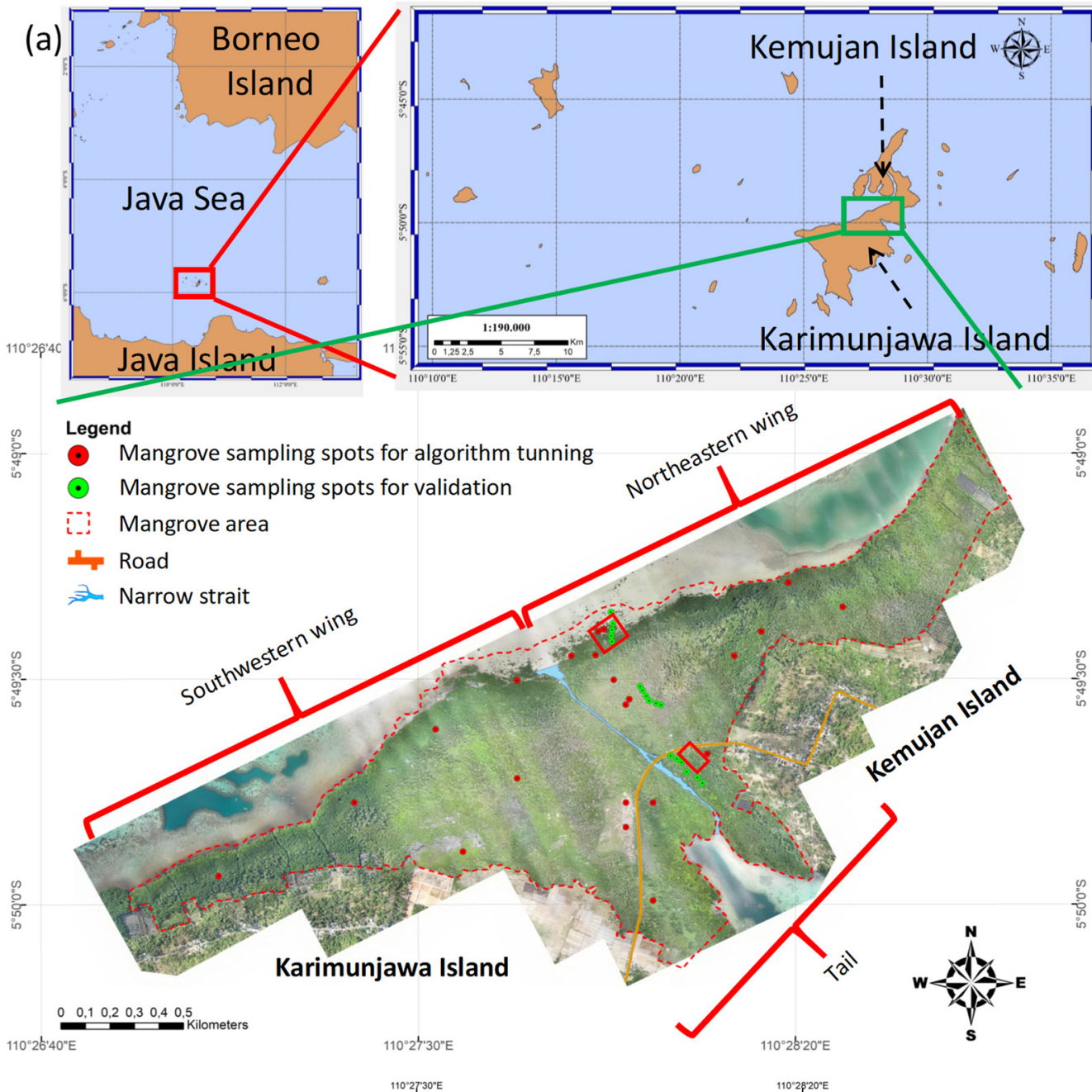

(b)

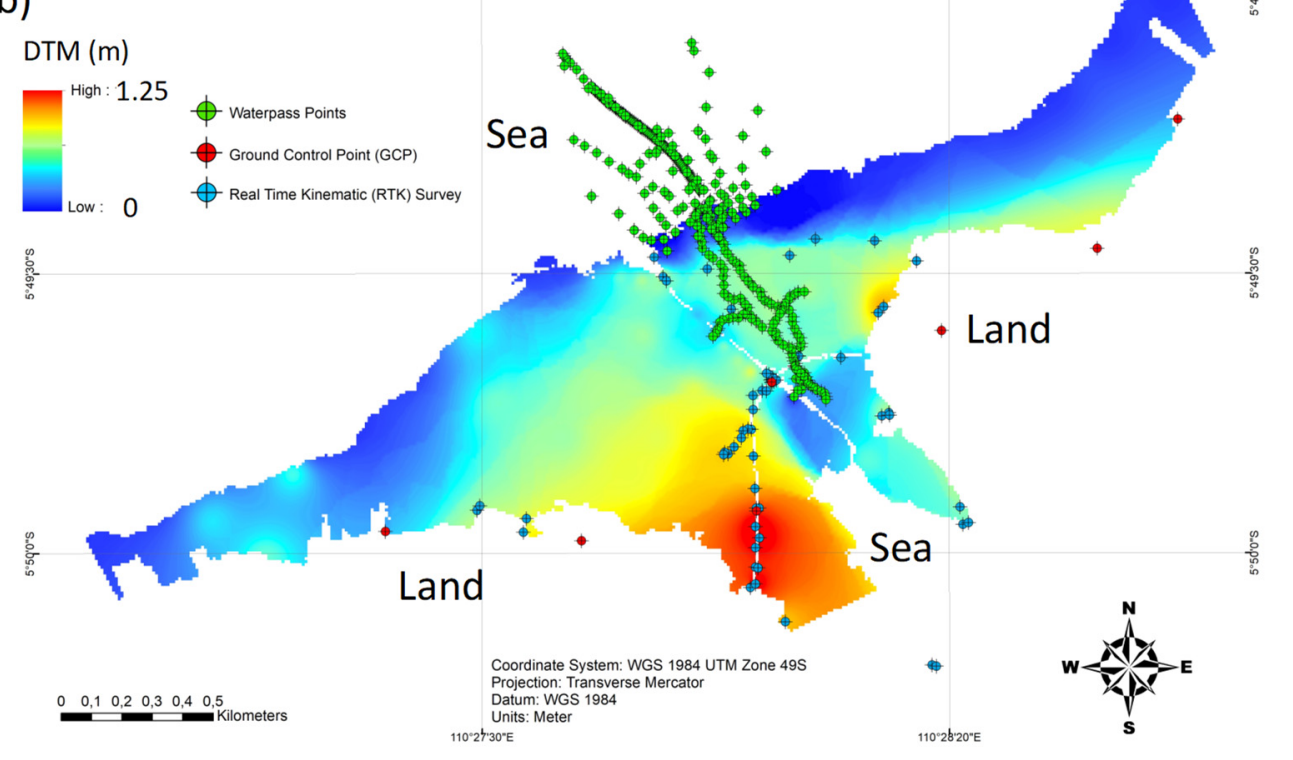

Figure 1. Study area. (a) Orthophoto of the study area. The red boxes are the study areas of Salim et al. [38]. The high resolution orthophoto is provided in the supplementary file. (b) Digital Terrain Model of the study area. 


\subsection{UAV Photogrammetry}

We used UAV photogrammetry taken from drone DJI Phantom 4 Pro subsequently processed using the Structure from Motion (SfM) Photogrammetry method to generate orthophoto, and Digital Surface Model (DSM) [39-42] for the Karimunjawa-Kemujan Islands. Orthophoto is the final seamless merging of true-color images of aerial photos, while DSM explains the elevation of earth surface from the mean sea level. We flew the drone above the study area with a $200-\mathrm{m}$ altitude and $80 \%$ overlapping images on 3-10 September 2019 and captured 2129 snapshots of aerial photos. The orthophoto, and DSM were generated through the mosaic process on these raw aerial photos, starting with aligning photos, then inputting Ground Control Point (GCP), building dense cloud, mesh, texture, and the last one is generating tile model of orthophoto and DSM (Figure 2). Aligning photos was conducted for producing early three dimensions (3D) model with GCPs as the reference. The dense point cloud contains millions of spot heights generated from the early 3D model. This dense point cloud was stitched into mesh then plotted into texture to obtain the physical 3D model of the study area. Noise filtering and surface smoothing were applied in the DSM generation with inverse distance weighting. The final spatial resolution of DSM and orthophoto is $5.38 \mathrm{~cm}$. This fine resolution of the orthophoto made it easily to delineate the mangrove area, as shown by the red dashed line in Figure 1a. Since the study area resembles the bird-shape anatomy, we divided the study area into three sub-area, i.e., the southwestern wing, northeastern wing, and tail areas, to simplify the spatial analysis. The tail area is located in the southeastern part of the study area bordered by the road. The southeastern and northwestern wing areas are connected by the narrow strait that separates Kemujan Island and Karimunjawa Island (Figure 1a).

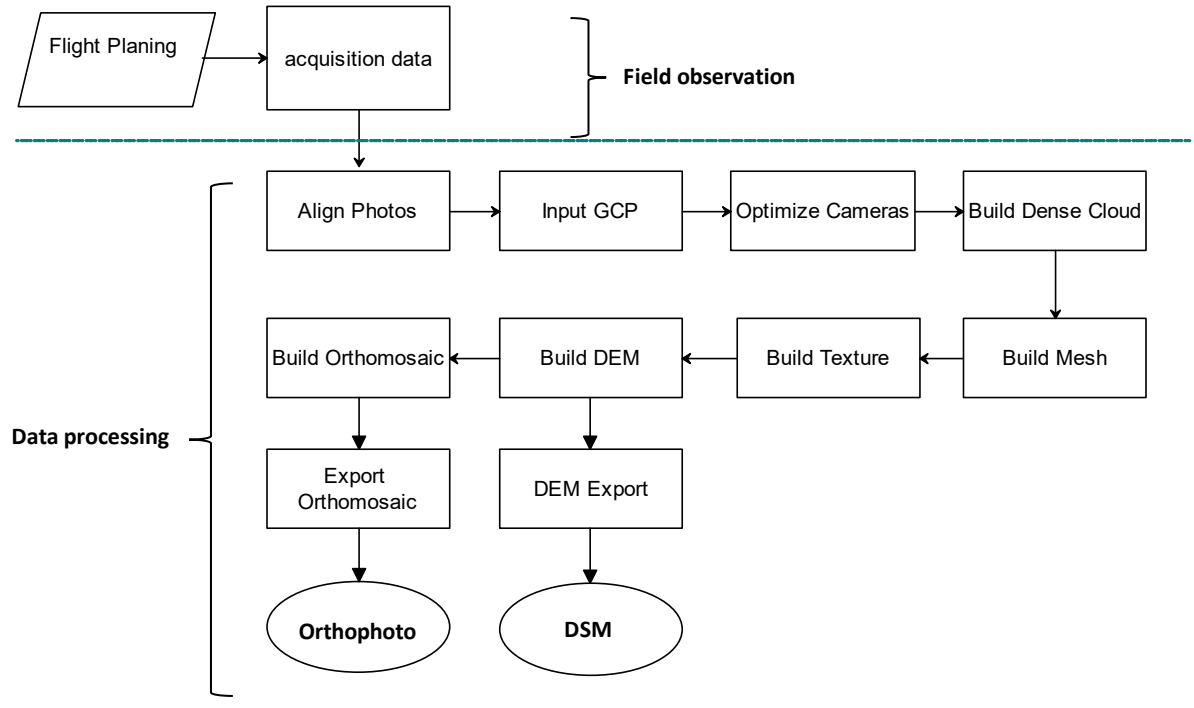

Figure 2. Workflow of SfM photogrammetry to produce orthophoto and DSM.

Regarding DSM, Shum and Kuo [43] stated that the accuracy of the 3D model from the aerial photos depends on the availability and distribution of GCP. In this study, 7 GCP were set and spatially distributed in the study area (Figure 1b) using GNSS Comnav T300 receiver with a static method. These GCPs represented the ground surface and were then also used for validating DSM. The RMSE of DSM is $0.17 \mathrm{~m}$. Another GNSS Comnav T300 receiver was also operated for a topographic survey with real-time kinematic (RTK) method for 60 spots in the study area. (Figure $1 \mathrm{~b}$ ). In addition, we conducted a water pass survey in 227 spots, as shown in Figure 1b. The combination of RTK spots was used to generate the Digital Terrain Model (DTM). The DTM explains the elevation of ground surface from the mean sea level. Technically, DTM can also be generated from aerial photos, e.g., [43,44] However, this technique cannot be applied in the Karimunjawa-Kemujan Islands since the dense mangroves in this area prevent the visible sensor of a drone camera to penetrate 
through the ground surface. Since the study area is flat, the DTM was generated from the interpolation of RTK spots. Then, DTM was validated with the elevation data obtained from the water pass survey. The RMSE of DTM is $0.08 \mathrm{~m}$. Kung et al. [44] stated that the accuracy of drone photogrammetry with GCPs ranges from $0.056 \mathrm{~m}$ to $1.25 \mathrm{~m}$. This indicates the high accuracy of the generated DSM and DTM in the present study.

Canopy height refers to the tree height above ground level. The distribution of mangrove canopy height in Kemujan-Karimunjawa Islands was estimated by simply subtracting the DSM with DTM.

\subsection{Mangrove Survey}

We conducted a mangrove survey on 27-30 September 2020 at 22 spots, as shown by the red dots in Figure 1a. We measured the arithmetic height and DBH, i.e. $1.3 \mathrm{~m}$ for 10 to 15 mangrove trees randomly selected within a radius of $10 \mathrm{~m}$ in each spot. In this study, spot selection for mangrove survey is crucial. Since the accuracy of the handheld Global Positioning System (GPS) for mangrove survey is much lower than the GNSS used for UAV photogrammetry reference, we selected the trees with similar height in each spot to reduce the possibility of the point mismatch between handheld GPS and GNSS. Next, the arithmetic height was converted into Lorey's height to estimate the mangrove biomass from the tree height. Lorey's height describes the weighted mean height whereby individual trees are weighted in proportion to their basal area. The calculation of Lorey's height was as follows:

$$
\begin{aligned}
H_{m} & =\frac{\sum_{i}^{N} B A_{i} x H_{i}}{\sum_{i}^{N} B A_{i}} \\
B A & =\pi x\left(\frac{D B H}{2}\right)^{2}
\end{aligned}
$$

where $H_{m}, H$, and $B A$ denote Lorey's height, arithmetic height, basal area, respectively. Then, Lorey's heights obtained from the red dots were used for generating an algorithm to calculate the canopy height from aerial photography. In addition, we used 17 spots of Lorey's height data from Suwa et al. [34] for validation, as shown by the green dots in Figure 1a.

\subsection{Calculation of Mangrove Above-Ground Biomass}

For estimating mangrove $A G B$, we used the $H_{m}-A G B$ relationship developed by Suwa et al. [34] which is generated for the region of Southeast and East Asia as follows:

$$
\ln A G B=0.81+1.81 \ln H_{m}
$$

The index of height used in the present study is Lorey's height, the basal area weighted height of all trees. Basal area weighting of tree heights increases the importance of the largest trees in a stand and represents the height of the stand's tallest trees $[45,46]$. The stand biomass (Mg/ha) depends mainly on large canopy trees having taller trees and Lorey's height can be good proxy for estimating the stand biomass. Therefore, many previous studies applied Lorey's height for estimating biomass e.g., [32-34]. Suwa et al. [34] also confirmed that Lorey's height showed a better fit to biomass data instead of arithmetic mean tree height (unpublished data). Thus, in the estimation of canopy height, Lorey's height has been known as one of the best indices.

Furthermore, the previous studies have suggested that the difference of Lorey's heightbiomass relationship among species is mainly explained by differences in $\mathrm{DBH}$, wood density and tree height $[47,48]$. In the case of the stand biomass estimation method in mangrove, Suwa et al. [34] tested if the Lorey's height-biomass relationships differ among different mangroves and found that the Lorey's height-biomass relationships differed significantly between canopy-closed and canopy-open mangroves, but the Lorey's height-biomass relationships did not differ among different types of mangroves within closed canopy forest 
types. Thus, Equation (3) is applicable since the mangroves in the Karimunjawa-Kemujan Islands is a closed canopy forest.

\section{Results}

\subsection{Canopy Height and Lorey's Height}

Based on the distribution of DSM, the elevation of surface mangrove area ranges from $2 \mathrm{~m}$ to $24 \mathrm{~m}$ (Figure 3a). Since the mangrove area of Karimunjawa-Kemujan Islands can be categorized as a flat plain, as denoted by the distribution of DTM which only varies from $0 \mathrm{~m}$ to $1.25 \mathrm{~m}$ (Figure $1 \mathrm{~b}$ ), calculated canopy height varies from 1 to $23 \mathrm{~m}$ (Figure $3 \mathrm{~b}$ ). The highest canopies are observed along the northwest edge of the southwestern wing area and the tail area near the seaside. A high canopy appearance is also observed in the middle of the northeastern wing, bordering the land vegetation area at its southeastern part. Comparing Figures $3 \mathrm{~b}$ and $1 \mathrm{a}$, it is also clear that the higher canopy is associated with a higher mangrove density, and vice versa.

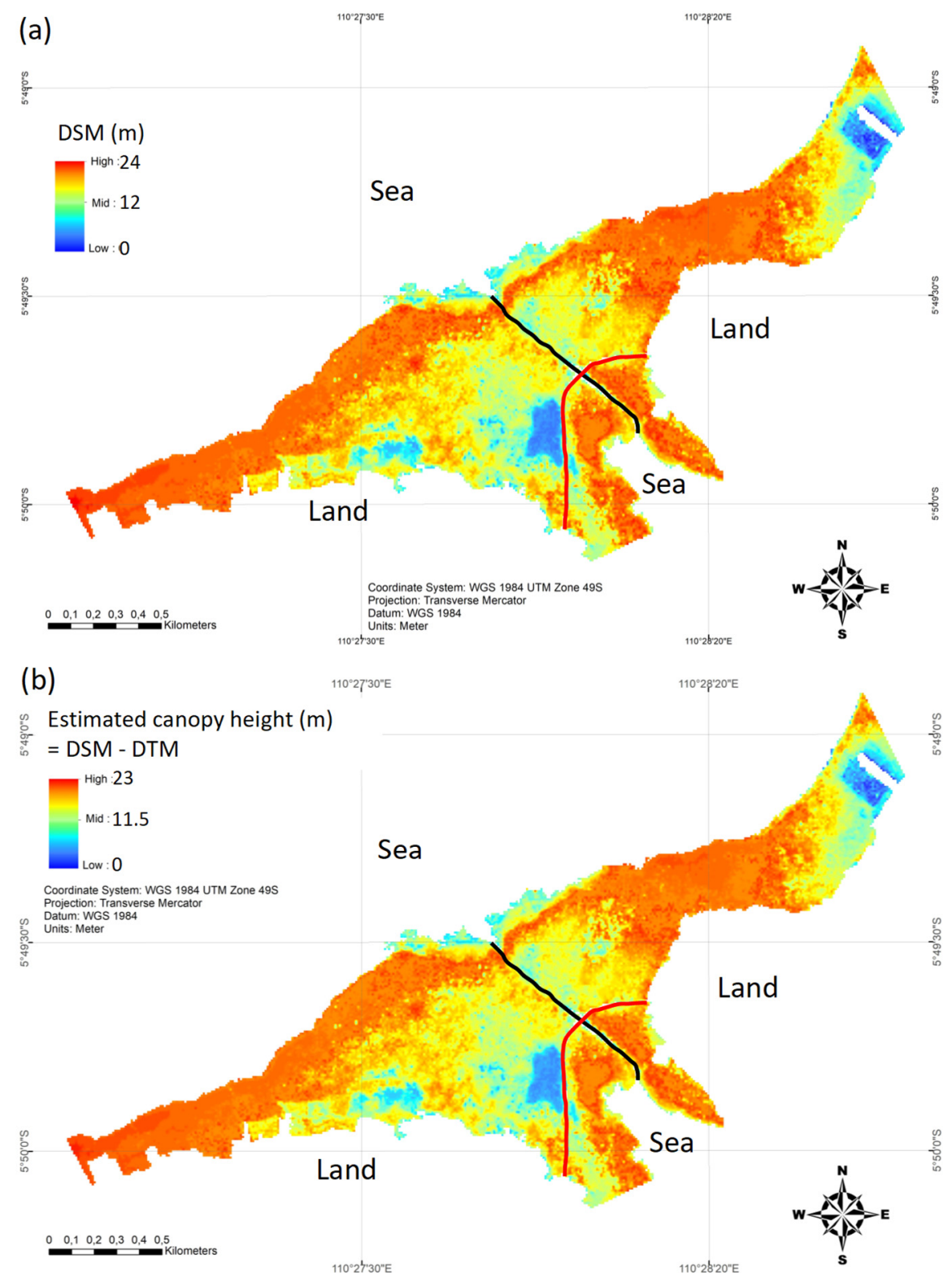

Figure 3. (a) Digital Surface Model (DSM) and (b) Calculated canopy height of mangroves in Karimunjawa-Kemujan Islands. The red and black lines are road and narrow strait, respectively. 
The relationship between the calculated canopy height and the observed Lorey's height is presented in Figure 4a. Mainly, calculated canopy heights are higher than observed Lorey's heights following the exponential pattern with a high determination coefficient $\left(\mathrm{R}^{2}\right)$, i.e., 0.83 . Thus, the conversion of the calculated canopy height into the calculated Lorey's height of aerial photography can be performed using the following equation:

$$
y=1.5614 e^{0.1153 x}
$$

where $y$ is the calculated Lorey's height, and $x$ is the calculated canopy height.
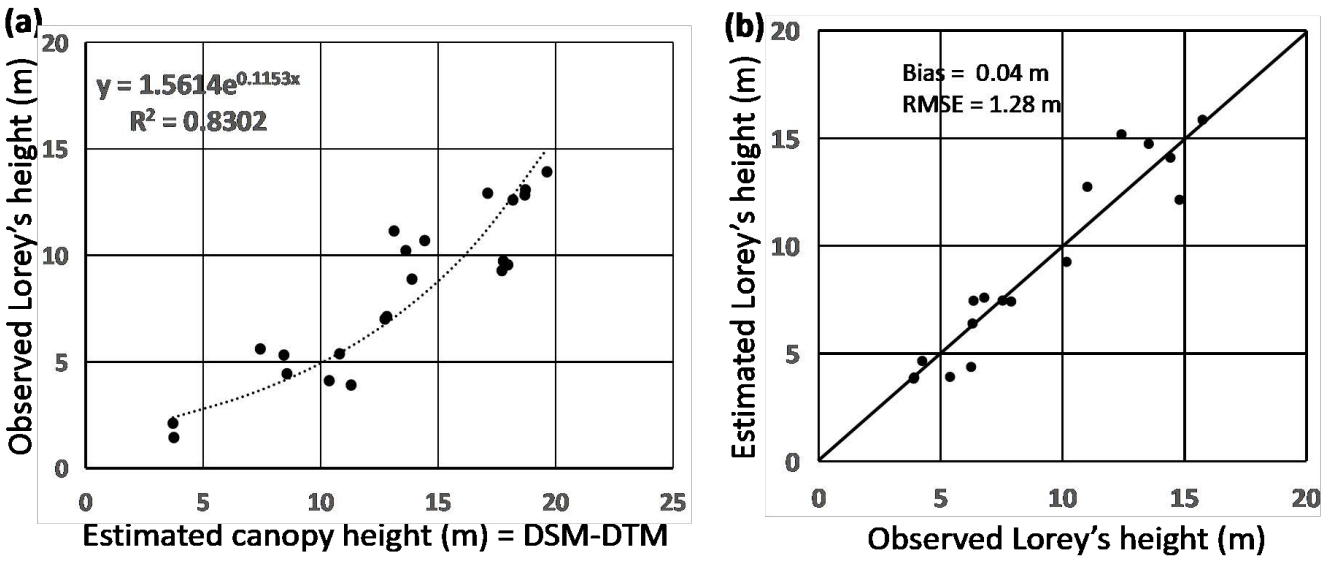

Figure 4. (a) Scatter plot of calculated canopy height and observed Lorey's height. (b) Scatter plot of observed Lorey's height and calculated Lorey's height. The position of observed Lorey's heights in (a) and (b) are denoted by red and green dots in Figure 1a, respectively.

To examine the accuracy of this equation, we validate the calculated Lorey's height with the observed Lorey's height from Suwa et al. [34] (Figure 4b). The bias and RMSE are $0.04 \mathrm{~m}$ and $1.28 \mathrm{~m}$, respectively. This error indicates that the accuracy of the calculated Lorey's height in the present study is lower than the previous studies which can show the vertical accuracy by less than $0.1 \mathrm{~m}$, e.g., $[15,49,50]$. The high error emerged in this study may come from the low accuracy of the handheld GPS used for mangrove sampling which caused the mismatched positions between the estimated Lorey's height and observed Lorey's height. However, this error is still much smaller than the RMSE obtained by Aslan et al. [26], who calculated the mangrove canopy height in Mimika District, Papua using a DEM Shuttle Radar Topographic Mission. With a spatial resolution of $30 \mathrm{~m}$, their RMSE is only $3.7 \mathrm{~m}$. Furthermore, since the maximum of Lorey's height in the present study is $\sim 15 \mathrm{~m}$, the RMSE of $1.28 \mathrm{~m}$ is still acceptable.

By applying Equation (4) to the distribution of canopy height (Figure 3b), we can obtain the spatial distribution of Lorey's height as shown in Figure 5. The distribution of Lorey's height in the study area ranges from $1 \mathrm{~m}$ to $15 \mathrm{~m}$. The maximum Lorey's height is observed at the Southwestern tip of the southeastern wing. Almost along the southwestern and northeastern wings coastline, the Lorey's height reaches more than $8 \mathrm{~m}$. At the tail area, which is also bordered by the sea, the Lorey's height also reaches more than $8 \mathrm{~m}$. Overall, we can see the clear border forming the narrow band of high Lorey's height facing the seaside. These heights are comparable with mangroves found in most areas in Indonesia, such as Bali [51], Porong Delta, East Java [52], Mahakam Delta [25], etc. But they are too short compared to the mangrove height in Papua, which can reach more than $40 \mathrm{~m}$ high, e.g., $[25,53,54]$. 


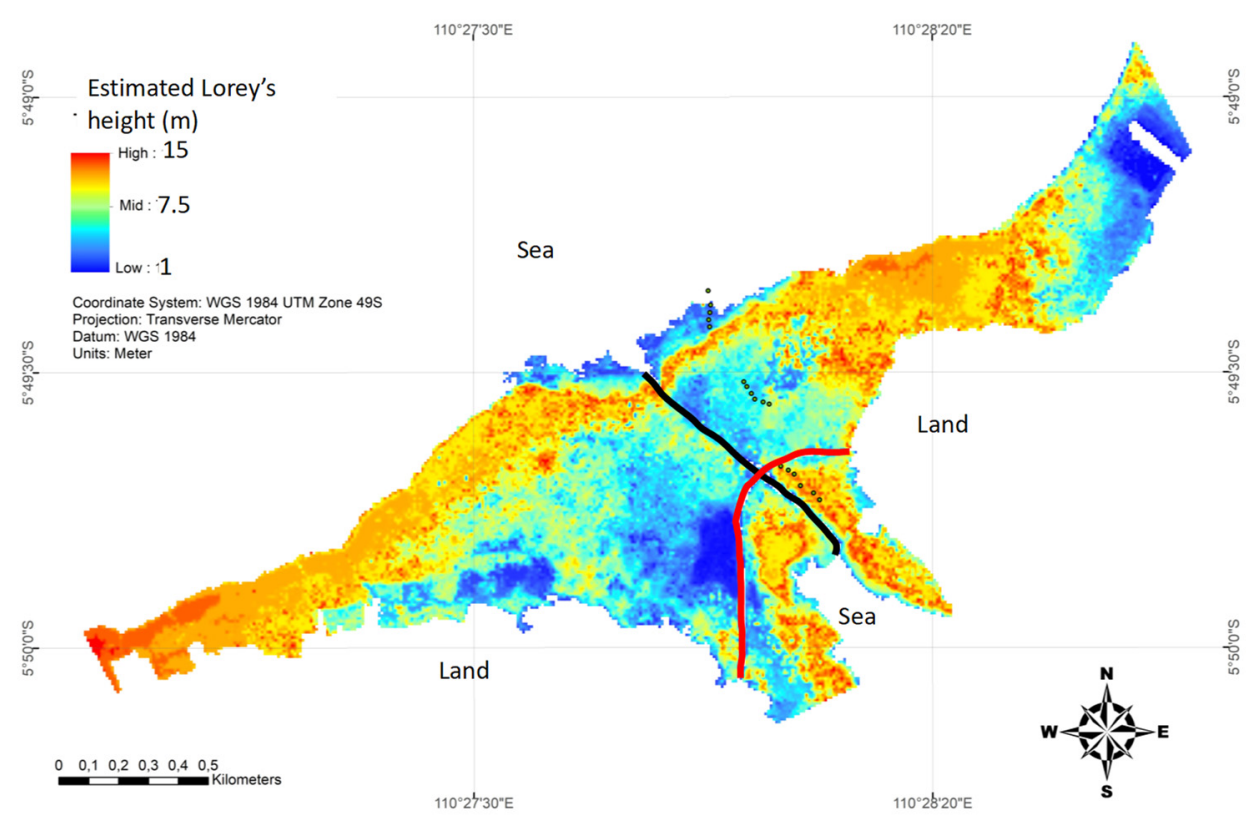

Figure 5. Calculated Lorey's height of mangroves in Karimunjawa-Kemujan Islands. The red and black lines are road and narrow strait, respectively.

On the other hand, stunted mangrove areas denoted by the lower Lorey's heights by less than $7.5 \mathrm{~m}$ are observed mostly in the inner areas that are not facing the sea directly. The lowest Lorey's height areas are found in the northeastern tip of the northeastern wing area and in the western side of the road in the southwestern wing area. The Lorey's height in these areas is only $1 \mathrm{~m}$. In the northwestern part of the narrow strait facing the sea, the Lorey's height also drops to less than $5 \mathrm{~m}$.

\subsection{Above Ground Biomass and Carbon Stock}

For estimating mangrove $A G B$, Equation (3) was simply applied to the distribution of Lorey's height (Figure 5), and the result can be seen in Figure 6. The AGB of mangroves in the Karimunjawa-Kemujan Islands ranges from $8 \mathrm{Mg} / \mathrm{ha}$ to $328 \mathrm{Mg} / \mathrm{ha}$. Suwa et al. [34] stated that the application of Equation (3) can produce a systematic error that suggests underestimating AGB for old mangroves whose AGB $>400 \mathrm{Mg} / \mathrm{ha}$. Since the distribution of AGB shown in Figure 6 is less than $400 \mathrm{Mg} / \mathrm{ha}$, Equation (3) is still applicable for estimating mangrove AGB in Karimunjawa-Kemujan Islands. The area with high Lorey's height has a high AGB biomass. Meanwhile, a low AGB biomass is observed in the stunted mangrove area.

Kauffman and Donato [13] stated that the carbon concentration of mangrove wood is usually a little less than $50 \%$. Thus, it is a common practice to convert AGB to carbon biomass by multiplying by $0.46-0.5$. In the present study, we used the multiplication of 0.5 to convert AGB to carbon biomass, as also implemented by Mudiyarso et al. [55]. The distribution of above-ground carbon biomass is also presented in Figure 6 with the half value of mangrove AGB. The carbon biomass of mangroves in the Karimunjawa-Kemujan Islands ranges from $4 \mathrm{Mg} \mathrm{C} /$ ha to $164 \mathrm{Mg} \mathrm{C} /$ ha with a mean value of $69.27 \mathrm{Mg} \mathrm{C} / \mathrm{ha}$. This value is higher than the mangrove AGB in other areas of Java Island such as Kaliwlingi, Brebes; Labuhan Lamongan; Ciletuh; and Segara Anakan, Cilacap which are only $6.49 \mathrm{Mg}$ $\mathrm{C} / \mathrm{ha}, 53.89 \mathrm{Mg} \mathrm{C} / \mathrm{ha}, 31.78 \mathrm{Mg} \mathrm{C} / \mathrm{ha}, 0.13 \mathrm{Mg} \mathrm{C} / \mathrm{ha}$, respectively [56-59]. With a total area of $238.98 \mathrm{ha}$, the potential above-ground carbon stored in the study area is estimated as $16,555.46 \mathrm{Mg}$. This result shows that mangroves in the Karimunjawa-Kemujan Islands store a huge amount of carbon. 


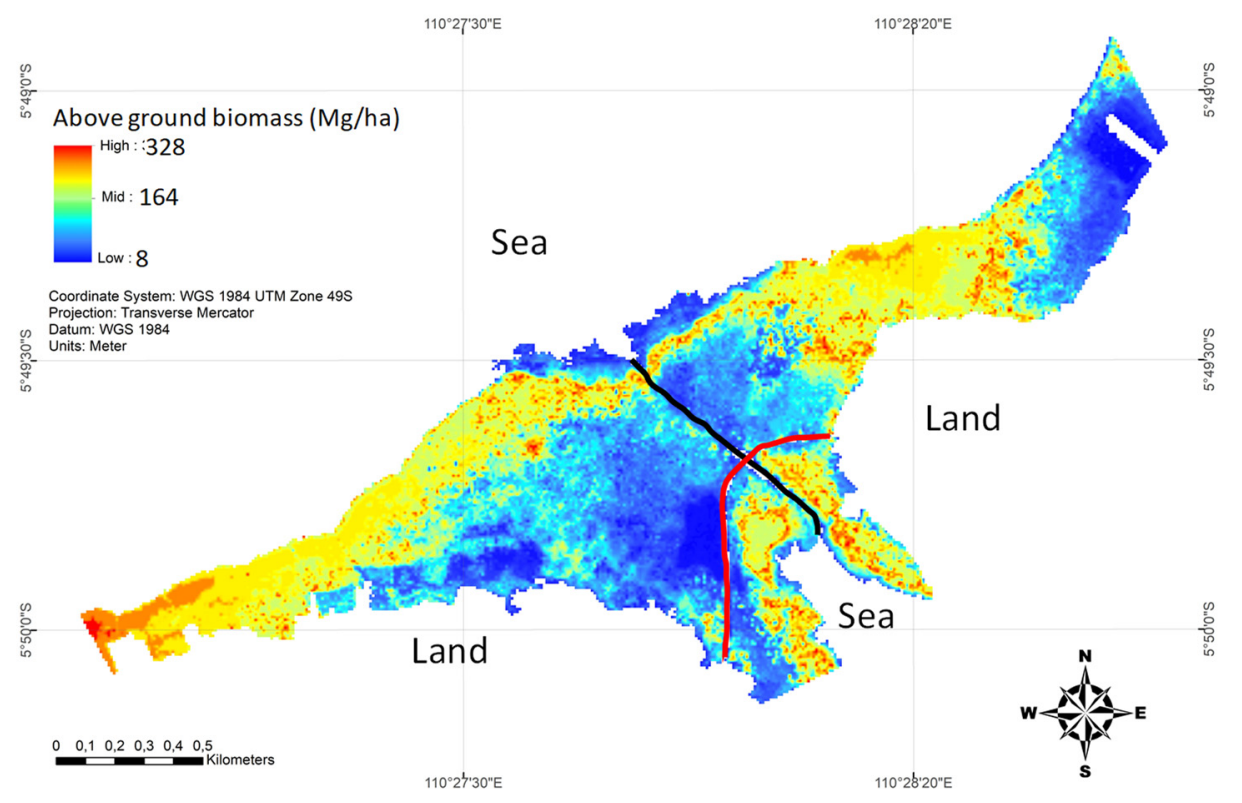

Figure 6. Above ground-biomass of Mangroves in Karimunjawa-Kemujan Islands. The value of above-ground carbon stock is $50 \%$ of the above-ground biomass. The red and black lines are road and narrow strait, respectively.

\section{Discussion}

The previous study of carbon stock estimation in Karimunjawa was conducted by Wicaksono et al. [22] using ALOS AVNIR2. Their analysis was based on the remote-sensing reflectance represented by leaf area index (LAI) and its correlation with the actual tree or root biomass carbon stock. Their result shows that the estimation of above-ground carbon in the Karimunjawa Islands is $216.4 \mathrm{MgC} /$ ha with a total value of $96,482 \mathrm{MgC}$ which is higher than the result of present study. The pattern of their spatial distribution of above-ground carbon biomass is similar to the present study. The higher carbon biomass is located in the area facing the sea. However, we provide a much higher resolution than their map due to the application of UAV imagery. The relation between the stunted mangrove with the low carbon biomass is clearly seen in the present study. Moreover, Wicaksono et al. [22] noted that the accuracy of the carbon stock estimations contains errors with one possible cause is related to the relationship between mangrove reflectance represented by LAI and mangrove AGB and carbon stock. In other words, there are uncertainties in converting the LAI into biomass. In the present study, the formula to convert Lorey's height to AGB has been tested and validated for the Karimunjawa-Kemujan Islands by Suwa et al. [34]. Thus, we provide the most accurate estimation of AGB for the area of the Karimunjawa-Kemujan Islands.

An attempt of UAV-imagery application for estimating mangrove biomass on Karimunjawa Island was conducted by Salim et al. [38]. They estimated mangrove AGB in 2 small areas of the Karimunjawa-Kemujan Islands (Figure 1a). They used Saenger and Snedaker [58]'s formula to convert mangrove height to mangrove AGB without any validation, resulting in their model's unknown bias and error. Their results also overestimate the present study. In the northern red box of Figure 1a, the tree height varies from $1 \mathrm{~m}$ to $15.5 \mathrm{~m}$ with an average of $4.4 \mathrm{~m}$, resulting in the estimated biomass of $82.154 \mathrm{Mg} / \mathrm{ha}$. In the southern red box of Figure 1a, the average tree height is 14.6, resulting in the estimated biomass of $192.674 \mathrm{Mg} / \mathrm{ha}$. Applying Equations (3) and (4), for the canopy height of $14.6 \mathrm{~m}$, the Lorey's height becomes $6.22 \mathrm{~m}$, and mangrove AGB is only $61.53 \mathrm{Mg} / \mathrm{ha}$. Thus, the conversion formula of Saenger and Snedaker [60] may not be suitable for the characteristics of mangroves in the Karimunjawa-Kemujan Islands.

Section 3.1 explains that there are the areas with the lowest Lorey's height, in the northeastern tip of the northeastern wing area and in the western side of the road in 
the southwestern wing area. Numerous aspects may cause stunted mangroves, such as sediment characteristics [61], nitrogen limitation [62], hypersaline soil [63,64], pollution [65], etc. Preliminary investigation of the substrate condition in the Karimunjawa-Kemujan Islands has been conducted by Hudoyo et al. [66]. Using the geoelectricity measurements, they indicated the thin sediments lying over the bedrock are the mangrove substrate in the Karimunjawa-Kemujan Islands. Bed rocks are found at less than 10-m depth. Furthermore, they also found the indication of hypersaline soil as denoted by the salinity larger than $40 \%$. Thus, the thin sediment and hypersaline soil may become the limiting factors for the mangrove growth in the Karimunjawa-Kemujan Islands. However, further investigation of these aspects is beyond the scope of the present study. These tasks are left for future works.

Next, it is also important to find the relation between the distribution of above ground carbon biomass and the distribution of mangrove species. Based on Karimunjawa National Park Office (BTNKJ) [35,36], mangroves in the Karimunjawa-Kemujan Islands consist of 24 species. BTNKJ [35] reported that the most dominant species of mangroves more than $10 \mathrm{~cm}$ in diameter at the Southwestern wing is Rhizophora sp. This may refer to the tall mangroves along the coastal line of the southeastern wing presented in this study. Near the narrow strait, the number of Rhizophora sp. decreases replaced with Lumnitzera sp., Ceriops tagal and Excoecaria agallocha. For the mangroves $5 \mathrm{~cm}$ to $10 \mathrm{~cm}$ in diameter, the most dominant species is Bruguiera sp. followed by Rhizophora apiculata, Ceriops tagal and Excoecaria agallocha which may refer to the stunted mangrove in the inner area of the southwestern wing. At the tail area, the tall mangroves are dominated by Scyphiphora hydrophyllacea and Rhizophora apiculata. However, short Scyphiphora hydrophyllacea also dominates in the tail area. At the northeastern wing, Lumnitzera sp. dominates the tall mangroves followed by Ceriops tagal, Excoecaria agallocha, and Rhizophora apiculata [36]. Furthermore, Ceriops tagal and Lumnitzera sp. are the dominant species for short mangroves. It is important to note that the inventory conducted by BTNKJ $[35,36]$ was based on the line transect in the mangrove area which may not describe the whole distribution of mangrove species. For future study, it is very important to generate an accurate map for the distribution of mangrove species to achieve a more reliable relationship between the distribution of height and species. The high-resolution orthophoto presented in this study (Figure 1a) will be helpful to identify mangrove species in Karimunjawa-Kemujan Islands and produce accurate species distribution map. This is left for future study.

As explained by Mudiyarso et al. [67], conservation of carbon-rich mangroves in the Indonesian archipelago should be a high-priority component of strategies for climate change mitigation. The calculated above-ground carbon stored in the Karimunjawa-Kemujan Islands is higher than other areas in Java Island, i.e., about 16,555.46 MgC in total and $69.72 \mathrm{MgC} / \mathrm{ha}$ or $6.972 \mathrm{MgC} / \mathrm{m}^{2}$ in average. This huge amount of carbon stored in the mangrove above ground biomass indicates the role of mangrove ecosystem in the KarimunjawaKemujan Islands in absorbing the atmospheric $\mathrm{CO}_{2}$ which is naturally released by the Java Sea. As an illustration, Latifah et al. [12] stated that the $\mathrm{CO}_{2}$ release by the seas surrounding Karimunjawa Islands ranges from 8.549 to $13.272 \mathrm{mmol} / \mathrm{m}^{2} /$ day with a mean value of about $10 \mathrm{mmol} / \mathrm{m}^{2} /$ day. This mean value is equal to $3.2 \mathrm{~g} \mathrm{C} / \mathrm{m}^{2} /$ day. This indicates that with the mean value of above-ground carbon biomass of $6.972 \mathrm{MgC} / \mathrm{m}^{2}$, each meter square of mangrove in the Karimunjawa-Kemujan Islands has absorbed and kept the carbon release from the seas surrounding Karimunjawa Islands for 2178 days $\approx$ almost 6 years. Noting that this illustration is only the simplification, further analysis by involving numerous biogeochemical factors including the complexity of anthropogenic factors is needed to obtain the accurate carbon cycle in the Karimunjawa Islands and their surrounding seas.

On the other hand, mangroves in Karimunjawa-Kemujan Islands have been under threats of conversion into intensive shrimp ponds, e.g., [68,69]. The reduction of the mangrove ecosystem will potentially cause a massive amount of $\mathrm{CO}_{2}$ to be released into the atmosphere, which increases the concentration of greenhouse gases [7,70,71]. Thus, mangrove forest protection in the Karimunjawa-Kemujan Islands and other blue carbon 
ecosystems such as seagrass, which can also store $4901.91 \mathrm{~g} \mathrm{C} / \mathrm{m}^{2}$, e.g., [72], will play an important role in sequestering parts of carbon release from the Java Sea for the mitigation of climate change. At a larger scale, Mudiyarso et al. [67] explained that massive aquaculture development in three decades has eliminated $40 \%$ of mangroves in Indonesia which resulted in an annual carbon emission of $0.07-0.21 \mathrm{Pg} \mathrm{CO}_{2}$. Thus, aggressive strategies from government, and stake holders are needed to protect and conserve the remaining mangroves as one of the key successes for mitigating climate change.

\section{Conclusions}

The Java Sea is known as a carbon source area that contributes to releasing carbon dioxide into the atmosphere. The blue carbon ecosystems in Karimunjawa Islands may play a vital role in absorbing and storing the released carbon emission. Karimunjawa Islands are located in the center of the Java Sea, which have been under the authority of the Karimunjawa National Park since 1999. The present study investigated the mangrove AGB and carbon stock in the Karimunjawa-Kemujan Islands, the largest mangrove area in the Karimunjawa Islands. Taking the aerial photos from an Unmanned Aerial Vehicle combined with GNSS measurements, we generated DSM and DTM with a high accuracy. The mangrove canopy height was calculated by subtracting DSM with DTM. Then, mangrove canopy height was converted into Lorey's height using exponential regression with our mangrove survey data. AGBs were calculated using an allometric equation destined for the Southeast and East Asia region. Above-ground carbon biomass is the multiplication of AGB by 0.5. Our regression model shows good accuracy to estimate mangrove Lorey's height in Karimunjawa-Kemujan Islands as denoted by the bias and RMSE of $0.04 \mathrm{~m}$ and $1.28 \mathrm{~m}$, respectively. The highest mangrove canopy is located along the coastline facing the sea, ranging from $8 \mathrm{~m}$ to $15 \mathrm{~m}$. Stunted mangroves $1 \mathrm{~m}$ to $8 \mathrm{~m}$ in height are detected mainly in the inner areas that are not facing the sea directly. AGB and carbon biomass of mangroves in the Karimunjawa-Kemujan Islands range from $8 \mathrm{Mg} / \mathrm{ha}$ to $328 \mathrm{Mg} / \mathrm{ha}$, and from $4 \mathrm{Mg} / \mathrm{ha}$ to $164 \mathrm{Mg} / \mathrm{ha}$, respectively. With a total area of $238.98 \mathrm{ha}$, the potential above-ground carbon stored in the study area is estimated as $16,555.46 \mathrm{Mg}$. This shows that mangroves in the Karimunjawa-Kemujan Islands store a huge amount of carbon. However, the massive development of shrimp ponds has been threatening the mangrove ecosystem in the Karimunjawa-Kemujan Islands. Thus, the government and stake holders should pay more attention to preserving the remaining mangrove in Karimunjawa-Kemujan Islands and implementing rehabilitation actions.

Author Contributions: Conceptualization, A.W., R.P. and N.S.A.; methodology, R.P., M.H. and S.B.I.; software, S.B.I.; validation, A.W. and L.M.; formal analysis, R.P. and D.N.S.; investigation, R.R.A., T.L.K., R.N.A.A., M.A.K., R.R. and T.N.; resources, N.S.A. and K.N.; data curation, S.B.I., L.M., D.N.S., R.R.A. and N.S.A.; writing—original draft preparation, A.W.; writing—review and editing, A.W., R.P., N.S.A. and R.S.; visualization, A.W. and S.B.I.; supervision, R.S. and K.N.; project administration, A.W., L.M. and D.N.S.; funding acquisition, A.W. All authors have read and agreed to the published version of the manuscript.

Funding: This research was funded by the Directorate General of Research and Development, the Ministry of Research and Technology, Republic of Indonesia, under the scheme "Fundamental Research" grant number 257-16/UN7.6.1/PP/2021 in collaboration with Science and Technology Research Partnership for Sustainable Development-Comprehensive Assessment and Conservation of Blue Carbon Ecosystems and their Services in the Coral Triangle (SATREPS-BlueCARES) Project granted to K.N., N.S.A., R.S., R.R., T.N, T.L.K., R.N.A.A. and M.A.K.

Institutional Review Board Statement: Not applicable.

Informed Consent Statement: Not applicable.

Data Availability Statement: The data is available at https:/ figshare.com/s/89bf86f79ef17f091ad2 (accessed on 1 August 2021). 

Acknowledgments: We thank to Karimunjawa National Park Office (BTNKJ) for the support and
permission to conduct field observation.

Conflicts of Interest: The authors declare no conflict of interest. The funders had no role in the design of the study; in the collection, analyses, or interpretation of data; in the writing of the manuscript, or in the decision to publish the results.

\section{References}

1. Friedlingstein, P.; Houghton, R.A.; Marland, G.; Hackler, J.; Boden, T.A.; Conway, T.J.; Canadell, J.G.; Raupach, M.R.; Ciais, P.; Le Quéré, C. Update on $\mathrm{CO}_{2}$ Emissions. Nat. Geosci. 2010, 3, 811-812. [CrossRef]

2. Jackson, R.B.; Le Quéré, C.; Andrew, R.M.; Canadell, J.G.; Korsbakken, J.I.; Liu, Z.; Peters, G.P.; Zheng, B. Global Energy Growth Is Outpacing Decarbonization. Environ. Res. Let. 2018, 13, 120401. [CrossRef]

3. Mcleod, E.; Chmura, G.L.; Bouillon, S.; Salm, R.; Björk, M.; Duarte, C.M.; Lovelock, C.E.; Schlesinger, W.H.; Silliman, B.R. A blueprint for blue carbon: Toward an improved understanding of the role of vegetated coastal habitats in sequestering $\mathrm{CO}_{2}$. Front. Ecol. Environ. 2011, 9, 552-560. [CrossRef]

4. Siikamäki, J.; Sanchirico, J.N.; Jardine, S.; McLaughlin, D.; Morris, D. Blue Carbon: Coastal Ecosystems, Their Carbon Storage, and Potential for Reducing Emissions. Environ. Sci. Policy Sustain. Develop. 2013, 55, 14-29. [CrossRef]

5. Alongi, D.M. Carbon cycling and storage in mangrove forests. Ann. Rev. Mar. Sci. 2014, 6, 195-219. [CrossRef] [PubMed]

6. Kauffman, J.B.; Bernardino, A.B.; Ferreira, T.O.; Giovannoni, L.R.; Gomes, L.E.O.; Romero, D.J.; Jimenez, L.C.Z.; Ruiz, F. Carbon stocks of mangroves and salt marshes of the Amazon region, Brazil. Biol. Lett. 2018, 2018, 20180208. [CrossRef] [PubMed]

7. Nellemann, C.; Corcoran, E.; Duarte, C.M.; Valdes, L.; De Young, C.; Fonseca, L.; Grimsditch, G. Blue Carbon. A Rapid Response Assessment; Grimsditch, G., Ed.; United Nations Environment Programme; GRID-Arendal: Arendal, Norway, 2009.

8. Donato, D.C.; Kauffman, J.B.; Murdiyarso, D.; Kurnianto, S.; Stidham, M.; Kanninen, M. Mangroves among the most carbon-rich forests in the tropics. Nat. Geosci. 2011, 4, 293-297. [CrossRef]

9. Donato, D.C.; Kauffman, J.B.; Mackenzie, R.A.; Ainsworth, A.; Pfleeger, A.Z. Whole-island carbon stocks in the tropical Pacific: Implications for mangrove conservation and upland restoration. J. Environ. Manag. 2012, 97, 89-96. [CrossRef]

10. Kartadikaria, A.R.; Watanabe, A.; Nadaoka, K.; Adi, N.S.; Prayitno, H.B.; Soemorumekso, S.; Muchtar, M.; Triyulianti, I.; Setiawan, A.; Suratno, S.; et al. $\mathrm{CO}_{2}$ sink/source characteristics in the tropical Indonesian seas. J. Geophys. Res. Oceans 2015, 120, 7842-7856. [CrossRef]

11. Wirasatriya, A.; Sugianto, D.N.; Maslukah, L.; Ahkam, M.F.; Wulandari, S.Y.; Helmi, M. Carbon dioxide flux in the Java Sea estimated from satellite measurements. Remote Sens. App. Soc. Environ. 2020, 20, 100376. [CrossRef]

12. Latifah, N.; Febrianto, S.; Wirasatriya, A.; Endrawati, H.; Zainuri, M.; Suryanti, S.; Hidayat, A.N. Air-Sea Flux of $\mathrm{CO}_{2}$ in the Waters of Karimunjawa Island, Indonesia. Saintek Perikan. Indones. J. Fish. Sci. Technol. 2020, 16, 171-178. [CrossRef]

13. Kauffman, J.B.; Donato, D.C. Protocols for The Measurement, Monitoring, and Reporting of Structure, Biomass and Carbon Stocks in: Mangrove Forests; CIFOR Working Paper; Center for International Forest Research: Bogor, Indonesia, 2012; pp. 1-86.

14. Picard, N.; Saint-André, L.; Henry, M. Manual for Building Tree Volume and Biomass Allometric Equations: From Field Measurement to Prediction; FAO: Roma, Italy, 2012.

15. Jones, A.R.; Segaran, R.R.; Clarke, K.D.; Waycott, M.; Goh, W.S.H.; Gillanders, B.M. Estimating Mangrove Tree Biomass and Carbon Content: A Comparison of Forest Inventory Techniques and Drone Imagery. Front. Mar. Sci. 2020, 6, 784. [CrossRef]

16. Hamilton, S.E.; Castellanos-Galindo, G.A.; Millones-Mayer, M.; Chen, M. Remote Sensing of Mangrove Forests: Current Techniques and Existing Databases. In Threats to Mangrove Forests: Hazards, Vulnerability, and Management; Makowski, C., Finkl, C.W., Eds.; Springer: Cham, Switzerland, 2018; pp. 497-520.

17. Simard, M.; Zhang, K.; Rivera-Monroy, H.V.; Ross, M.S.; Ruiz, P.L.; Castañeda-Moya, E.; Twilley, R.R.; Rodriguez, E. Mapping Height and Biomass of Mangrove Forests in Everglades National Park with SRTM Elevation Data. Photogram. Eng. Remote Sens. 2006, 72, 299-311. [CrossRef]

18. Li, X.; Gar-On Yeh, A.; Wang, S.; Liu, K.; Liu, X.; Qian, J.; Chen, X. Regression and Analytical Models for Estimating Mangrove Wetland Biomass in South China Using Radarsat Images. Int. J. Remote Sens. 2007, 28, 5567-5582. [CrossRef]

19. Fatoyinbo, T.E.; Simard, M.; Washington-Allen, R.A.; Shugart, H.H. Landscape-Scale Extent, Height, Biomass, and Carbon Estimation of Mozambique's Mangrove Forests with Landsat ETM+ and Shuttle Radar Topography Mission Elevation Data. J. Geophys. Res. Biogeosci. 2008, 113, 1-13. [CrossRef]

20. Fatoyinbo, T.E.; Armstrong, A.H. Remote Characterization of Biomass Measurements: Case Study of Mangrove Forests. In Biomass; Momba, M., Bux, F., Eds.; Sciyo: Rijeka, Croatia, 2010.

21. Hamdan, O.; Aziz, H.K.; Hasmadi, I.M. L-Band ALOS PALSAR for Biomass Estimation of Matang Mangroves, Malaysia. Remote Sens. Environ. 2014, 155, 69-78. [CrossRef]

22. Wicaksono, P.; Danoedoro, P.; Hartono; Nehren, U. Mangrove biomass carbon stock mapping of the Karimunjawa Islands using multispectral remote sensing. Int. J. Remote Sens. 2016, 37, 26-52. [CrossRef]

23. Rahman, A.F.; Aslan, A. The first global-scale $30 \mathrm{~m}$ resolution mangrove canopy height map using Shuttle Radar Topography Mission data. arXiv 2017, arXiv:170609958. 
24. Lee, S.; Fatoyinbo, T.E.; Lagomasino, D.; Osmanoglu, B.; Simard, M.; Trettin, C.; Rahman, M.; Ahmed, I. Large-scale mangrove canopy height map generation from TanDEMX data by means of Pol-InSAR techniques. In Proceedings of the 2015 IEEE International Geoscience and Remote Sensing Symposium (IGARSS), Milan, Italy, 26-31 July 2015.

25. Aslan, A.; Rahman, A.F.; Robeson, S.M. Investigating the use of Alos Prism data in detecting mangrove succession through canopy height estimation. Ecol. Indic. 2018, 87, 136-143. [CrossRef]

26. Aslan, A.; Rahman, A.F.; Warren, M.W.; Robeson, S.M. Mapping spatial distribution and biomass of coastal wetland vegetation in Indonesian Papua by combining active and passive remotely sensed data. Remote Sens. Environ. 2016, 183, 65-81. [CrossRef]

27. Owers, C.J.; Rogers, K.; Woodroffe, C.D. Spatial variation of aboveground carbon storage in temperate coastal wetlands. Estuar. Coast. Shelf Sci. 2018, 210, 55-67. [CrossRef]

28. Anderson, K.; Gaston, K.J. Lightweight unmanned aerial vehicles will revolutionize spatial ecology. Front. Ecol. Environ. 2013, 11, 138-146. [CrossRef]

29. Panagoitidis, D.; Abdollahnejad, A.; Surovı, P.; Chiteculo, V. Determining tree height and crown diameter from high-resolution UAV imagery AU-Panagiotidis, Dimitrios. Int. J. Remote Sens. 2017, 38, 2392-2410. [CrossRef]

30. Bendig, J.; Yu, K.; Aasen, H.; Bolten, A.; Bennertz, S.; Broscheit, J.; Gnyp, M.L.; Bareth, G. Combining UAV-based plant height from crop surface models, visible, and near infrared vegetation indices for biomass monitoring in barley. Int. J. Appl. Earth Observ. Geoinform. 2015, 39, 79-87. [CrossRef]

31. Navarro, A.; Young, M.; Allan, B.; Carnell, P.; Macreadie, P.; Ierodiaconou, D. The application of Unmanned Aerial Vehicles (UAVs) to estimate above-ground biomass of mangrove ecosystems. Remote Sens. Environ. 2020, 242, 111747. [CrossRef]

32. Simard, M.; Fatoyinbo, L.; Smetanka, C.; Rivera-Monroy, V.H.; Castaneda-Moya, E.; Thomas, N.; Van, S.T. Mangrove canopy height globally related to precipitation, temperature and cyclone frequency. Nat. Geosci. 2019, 12, 40-45. [CrossRef]

33. Saatchi, S.S.; Harris, N.L.; Brown, S.; Lefsky, M.; Mitchard, E.T.A.; Salas, W.; Zutta, B.R.; Buermann, W.; Lewis, S.L.; Hagen, S.; et al. Benchmark map of forest carbon stocks in tropical regions across three continents. Proc. Natl. Acad. Sci. USA 2011, 108, 9899-9904. [CrossRef]

34. Suwa, R.; Rollon, R.; Sharma, S.; Yoshikai, M.; Albano, G.M.G.; Ono, K.; Adi, N.S.; Ati, R.N.A.; Kusumaningtyas, M.A.; Kepel, T.L.; et al. Mangrove biomass estimation using canopy height and wood density in the South East and East Asian regions. Est. Coast. Shelf Sci. 2020, 248, 106937. [CrossRef]

35. Balai Taman Nasional Karimunjawa (BTNKJ). Report of Mangrove Inventory at Karimunjawa Island; BTNKJ: Semarang, Indonesia, 2013; pp. 1-28. (In Bahasa)

36. Balai Taman Nasional Karimunjawa (BTNKJ). Report of Mangrove Inventory at Kemujan Island; BTNKJ: Semarang, Indonesia, 2013; pp. 1-31. (In Bahasa)

37. Kamal, M.; Phinn, S.; Johansen, K. Assessment of multi-resolution image data for mangrove leaf area index mapping. Remote Sens. Environ. 2016, 176, 242-254. [CrossRef]

38. Salim, H.L.; Adi, N.S.; Kepel, T.L.; Ati, R.N.A. Estimating mangrove biomass using drone in Karimunjawa Islands. IOP Conf. Ser. Earth Environ. Sci. 2020, 561, 012054. [CrossRef]

39. Cunliffe, A.M.; Brazier, R.E.; Anderson, K. Ultra- fine grain landscape-scale quantification of dry land vegetation structure with drone-acquired structure-from-motion photogrammetry. Remote Sens. Environ. 2016, 183, 129-143. [CrossRef]

40. Mouloua, S.A.; Ferraro, J.; Mouloua, M.; Hancock, P.A.; Florida, C. Trend analysis of Unmanned Aerial Vehicles (UAV). HFES Proc. 2018, 62, 1067-1071. [CrossRef]

41. Polat, N.; Murat, U. An Experimental Analysis of Digital Elevation Models Generated with Lidar Data and UAV Photogrammetry. J. Indian Soc. Remote Sens. 2018, 46, 1135-1142. [CrossRef]

42. Wirasatriya, A.; Helmi, M.; Fauzi, R.F.; Harsono, G.; Rahmadi, P.; Kusumastuti, W.; Iryanthony, S.B.; Ramadhani, Y.H.; Dharmawan, I.W.E. Estimation of Sea Level Rise threat on the existence of the three northeastern and outermost small islands of Indonesia (i.e., Liki, Bepondi and Miossu Islands) using remote sensing method. Disaster Adv. 2020, 13, 30-41.

43. Shum, C.; Kuo, C. Observation and geophysical causes of present-day sea level rise Chapter 7. In Climate Change and Food Security in South Asia; Lal, R., Sivakumar, M., Faiz, S.M.A., Rahman, A.H.M.M., Islam, K.R., Eds.; Springer: Amsterdam, The Netherlands, 2010.

44. Kung, O.; Strecha, C.; Beyeler, A.; Zufferey, J.-C.; Floreano, D.; Fua, P.; Gervaix, F. The accuracy of automatic photogrametric techniques on Ultra-light UAV Imagery, In Proceedings of the International Conference on Unmanned Aerial Vehicle in Geomatics (UAV-g), IAPRS, Zurich, Switzerland, 14-16 September 2011.

45. Lefsky, M.A. A global forest canopy height map from the moderate resolution imaging spectroradiometer and the geoscience laser altimeter system. Geophys. Res. Lett. 2010, 37, L15401. [CrossRef]

46. Lugo, A.E.; Snedaker, S.C. The Ecology of Mangroves. Ann. Rev. Ecol. System. 1974, 5, 39-64. [CrossRef]

47. Chave, J.; Brown, A.C.S.; Cairns, M.A.; Cahmbers, J.Q.; Eamus, D.; Folster, H.; Fromad, F.; Higuchi, N.; Kira, T.; Lescure, J.P.; et al. Tree allometry and improved estimation of carbon stocks and balance in tropical forests. Oecologia 2005, 145, 87-99. [CrossRef] [PubMed]

48. Komiyama, A.; Poungparn, S.; Kato, S. Common allometric equations for estimating the tree weight of mangroves. J. Trop. Ecol. 2005, 21, 471-477. [CrossRef] 
49. Otero, V.; Van De Kerchove, R.; Satyanarayana, B.; Martínez-Espinosa, C.; Fisol, M.A.B.; Ibrahim, M.R.B.; Sulong, I.; MohdLokman, H.; Lucas, R.; Dahdouh-Guebas, F. Managing mangrove forests from the sky: Forest inventory using field data and Unmanned Aerial Vehicle (UAV) imagery in the Matang Mangrove Forest Reserve, peninsular Malaysia. Forest Ecol. Manag. 2018, 411, 35-45. [CrossRef]

50. Kustiyanto, E. Estimating Aboveground Biomass/Carbon Stock and Carbon Sequestration Using UAV (Unmanned Aerial Vehicle) in Mangrove Forest, Mahakam Delta, Indonesia. Master's Thesis, Faculty of Geo-Information Science and Earth Observation of the University of Twente, Enschede, The Netherlands, February 2019.

51. Viennois, G.; Proisy, C.; Féret, J.B.; Prosperi, J.; Sidik, F.; Suhardjono; Rahmania, R.; Longepé, N.; Germain, O.; Gaspar, P. Multitemporal Analysis of High-Spatial-Resolution Optical Satellite Imagery for Mangrove Species Mapping in Bali, Indonesia. IEEE J. Sel. Top. Appl. Earth. Obs. Remote Sens. 2016, 9, 3680-3686. [CrossRef]

52. Beselly, S.M.; van der Wegen, M.; Grueters, U.; Reyns, J.; Dijkstra, J.; Roelvink, D. Eleven Years of Mangrove-Mudflat Dynamics on the Mud Volcano-Induced Prograding Delta in East Java, Indonesia: Integrating UAV and Satellite Imagery. Remote Sens. 2021, 13, 1084. [CrossRef]

53. Alongi, D.M. Mangrove forests of Papua. In The Ecology of Papua, Part Two; Marshall, A., Beehler, B.M., Eds.; Periplus: Singapore, 2007; pp. 824-857.

54. Setyadi, G.; Pribadi, R.; Wijayanti, D.P.; Sugianto, D.N. Mangrove diversity and community structure of Mimika District, Papua, Indonesia. Biodivers. J. Biol. Divers. 2021, 22, 3562-3570. [CrossRef]

55. Mudiyarso, D.; Widodo, M.; Suyanto, D. Fire risks in forest carbon projects in Indonesia. Sci. China (Ser. C) 2002, $45,65-74$.

56. Nugraha, F.W.; Pribadi, R.; Wirasatriya, A. Study of areal changes for predicting carbon stock of mangrove ecosystem in Kaliwlingi Village, Brebes Regency. Bul. Oseanografi Mar. 2020, 9, 104-116. (In Bahasa) [CrossRef]

57. Asadi, M.A.; Yona, D.; Saputro, S.E. Species Diversity, Biomass, and Carbon Stock Assessments of Mangrove Forest in Labuhan, Indonesia. IOP Conf. Ser. Earth Environ. Sci. 2018, 151, 012009. [CrossRef]

58. Kusmana, C.; Hidayat, T.; Hikmah, W.F. Above-Ground Biomass and Carbon Stock of Ciletuh Mangrove Forest, West Java, Indonesia. IOP Conf. Ser. Earth Environ. Sci. 2019, 394, 012005. [CrossRef]

59. Widyastuti, A.; Yani, E.; Nasution, E.K.; Rochmatino. Diversity of mangrove vegetation and carbon sink estimation of Segara Anakan Mangrove Forest, Cilacap, Central Java, Indonesia. Biodiversitas 2018, 19, 246-252. [CrossRef]

60. Saenger, P.; Snedaker, S.C. Pantropical trends in mangrove above-ground biomass and annual litterfall. Oecologia 1993, 96, 293-299. [CrossRef]

61. Yang, J.; Gao, J.; Cheung, A.; Liu, B.; Schwendenmann, L.; Costello, M.J. Vegetation and sediment characteristics in an expanding mangrove forest in New Zealand. Est. Coast. Shelf Sci. 2013, 134, 11-18. [CrossRef]

62. Anton, A.; Almahasheer, H.; Delgado, A.; Garcias-Bonet, N.; Carrillo-de-Albornoz, P.; Marbà, N.; Hendriks, I.E.; Krause-Jensen, D.; Saderne, V.; Baldry, K.; et al. Stunted Mangrove Trees in the Oligotrophic Central Red Sea Relate to Nitrogen Limitation. Front. Mar. Sci. 2020, 7, 597. [CrossRef]

63. Purvaja, R.; Ramesh, R.; Frenzel, P. Plant-mediated methane emission from an Indian mangrove. Glob. Chang. Biol. 2004, 10, 1825-1834. [CrossRef]

64. Ellison, J.C.; Simmonds, S. Structure and productivity of inland mangrove stands at Lake MacLeod, Western Australia. J. R. Soc. West. Aust. 2003, 86, 25-30.

65. Mandura, A.A. Mangrove stand under sewage pollution stress: Red Sea. Mangroves Salt Marshes 1997, 1, 255-262. [CrossRef]

66. Hudoyo, F.; Widada, S.; Maslukah, L.; Rochaddi, B.; Wirasatriya, A.; Adi, N.S. Study of tide, distribution of shallow ground water and sediment and their relation to the mangrove distribution in the Karimunjawa Islands. Indones. J. Oceanogr. 2021, 3, 78-87. (In Bahasa)

67. Murdiyarso, D.; Purbopuspito, J.; Kauffman, J.B.; Warren, M.W.; Sasmito, S.D.; Donato, D.C.; Manuri, S.; Krisnawati, H.; Taberima, S.; Kurnianto, S. The Potential of Indonesian Mangrove Forests for Global Climate Change Mitigation. Nat. Clim. Chang. 2015, 5, 1089-1092. [CrossRef]

68. Puryono, S.; Suryanti, S. Degradation of Mangrove Ecosystem in Karimunjawa Island Based on Public Perception and Management. IOP Conf. Ser. Earth Environ. Sci. 2019, 246, 012080. [CrossRef]

69. Rizki, N.; Maslukah, L.; Sugianto, D.N.; Wirasatriya, A.; Zainuri, M.; Ismanto, A.; Purnomo, A.R.; Ningrum, A.D. Distribution of DO (Dissolved Oxygen) and BOD (Biological Oxygen Demand) in the Waters of Karimunjawa National Park using TwoDimensional Model Approach. IOP Conf. Ser. Earth Environ. Sci. 2021, 750, 012014. [CrossRef]

70. Ong, J.E. The Hidden Costs of Mangrove Services: Use of Mangroves for Shrimp Aquaculture. In International Science Roundtable for the Media; ICSU, IGBP, IHDP, WCRP, DIVERSITAS, START: Bali, Indonesia, 2002.

71. Granek, E.; Ruttenberg, B.I. Changes in Biotic and Abiotic Processes following Mangrove Clearing. Est. Coast. Shelf Sci. 2008, 80, 555-562. [CrossRef]

72. Wirasatriya, A.; Nurrahman, M.N.; Maslukah, L.; Wulandari, S.Y.; Sugianto, D.N.; Adi, N.S. Role of the Seagrass Bed at Kemujan Island, Karimunjawa Islands, Indonesia, as a Carbon Sink Area. Int. J. Clim. Chang. Impacts Resp. 2021, 14, 33-43. [CrossRef] 